\title{
( Run Gauntlets or Pay Pirates? Regulating Vessel aße Speeds in High-Risk Waters
}

\section{Ryan W. McDowell}

College of Law, University of Tennesee College of Law, The University of Tennessee, Knoxville, Tennessee 37996, USA

E-mail for correspondence: ryan.mcdowell95@gmail.com

\begin{abstract}
Maritime commerce in world commerce. Each year, vessels carry more cargo at higher costs and faster speeds. Insurance is an integral part of shipping, as it protects cargoes and crews against the perils of the sea. This Article focuses on the peril of piracy, a criminal practice that has evolved significantly throughout history. Pirates today, as pirates of the past, prey upon the unprotected. Yet, modern piracy, unlike historical piracy, is essentially non-violent. The modern pirate profits from ransom, not theft. Today, piracy is a monetary risk with computable consequences: an insurable threat. Anti-piracy methods, including insurance, impose steep costs to world trade. In the past decade, pirate activity has declined while piracy insurance has grown more expensive. This phenomenon is problematic, but an industry-wide solution is a challenging construct. To handle the costly risks of piracy is to balance the distinct and competing interests of ship-owners, insurers, operators, and governments. As this Article argues, insurance can more efficiently mitigate piracy's puzzling risk. After discussing maritime piracy and maritime insurance, this Article outlines the legal and regulatory schema for a system to mandate the speeds of vessels that transit pirate-prone waters. The proposed regulation is mechanically sound, logistically feasible, cost-effective, and enforceable. To diminish the costly risk of piracy, this Article proposes revising a treaty to afford the International Maritime Organization (IMO) jurisdiction to regulate vessel speeds on the high seas.
\end{abstract}

Keywords: maritime piracy, maritime insurance, slow steaming, high risk areas, kidnap and ransom insurance, maritime commerce, anti-piracy, international law, law of trade and commerce, knots, vessel speeds, international maritime organization

\section{INTRODUCTION}

It is no surprise that ocean trade is ninety percent of world trade, as ocean vessels are more cost-effective than any other carriage vehicles in modern use. ${ }^{1}$ The efficient and consistent function of these vessels is vital to global economic health - nothing less than a requisite of the dayto-day commercial activity in industries worldwide.

\footnotetext{
${ }^{1}$ See UNCTAD, REVIEW OF MARITIME TRANSPORT 2019 (2020) (ocean trade is $90 \%$ of world trade); $i d$. at ix-xi (vessel groupings, constituencies, world fleet by tonnage, type, carrier $-60,000$ vessels trading 11 billion tons of cargo). See generally Liner Shipping Connectivity Index, UNCTADSTAT (May 14, 2020), https://unctadstat.unctad.org/wds/TableViewer/tableView.as px?ReportId=92.
}

Fortunately, maritime trade is robust, seemingly unshakable throughout global crises or events that suspend other business activity. Even now, as the COVID19 pandemic endangers public health and quarantines large populations, the world's cargo vessels are circling the Cape of Good Hope, skirting the West Indies, and transiting the Suez Canal. ${ }^{2}$ As always, ocean trade moves humanity's goods at humanity's pace.

\footnotetext{
2 See, e.g., Marine Traffic, EXACTEARTCH (AIS) (2020) https://www.marinetraffic.com/en/ais/home/ (last visited May 14, 2020); see also The Lloyd's List Podcast, Piracy in a Time of Coronavirus, LLOYD'S LIST INFORMA (Apr. 3, 2020) https:/ /loydslist.maritimeintelligence.informa.com/LL1131816 /The-Lloyds-List-Podcast-Piracy-in-a-time-of-coronavirus (discussing the constraining effects of 14-day vessel quarantines
} 
Despite its stability, however, the shipping industry faces recurring obstacles that call for cooperative and innovative solutions. The global response to these challenges defines both the advancements and the limitations of shipping practice. The methods used to control modern shipping directly affect the global economy.

For this reason, states have formed international bodies with the authority to manage and safeguard the various aspects of shipping. ${ }^{3}$ Through these bodies, states collectively supervise the shipping industry and, ultimately, cooperate to form rules that shape its future. Today, these organizations seek solutions to problems that include decarburization, accretion, and various geopolitical conflicts - it is a rigorous process of constant review. ${ }^{4}$ This Article seeks to contribute to that process.

Part II of this Article summarizes the history, evolution, and practice of maritime piracy. Surveying both documented history and recent developments, Part III summarizes the costs attributable to piracy, largely relating to countermeasures and insurance. Part IV draws from academic literature and public records to examine the underlying structure, mechanisms, and trends of the maritime insurance market. Part VI prescribes a specific, workable regulatory framework to efficiently counteract the risks and costs of maritime piracy by regulating vessel speeds. Part VII considers the results of implementing the presented framework, the potential limitations of the Article's research, and areas for further research.

\section{The Evolution of Maritime Piracy}

Piracy is a plague to human trade nearly as old as humankind itself. ${ }^{5}$ Piracy was born as ships began crossing the seas, fueled by early pirates' rampant theft of defenseless, valuable cargo aboard early civilian vessels.

and stevedore deficiencies at port terminal facilities, especially in chokepoint waters like the Gulf of Guinea which, notably, has recorded one half of the piracy incidents in the past two years).

${ }^{3}$ These entities include organizations such as the International Shipping Council (ICS), the World Shipping Council (WSC), the Maritime Safety Committee (MSC), and the International Maritime Organization (IMO), a branch of the United Nations with authority to regulate shipping activity. See, e.g., The International Convention for The Prevention of Pollution of the Sea by Oil (OILPOL) (1954) (multi-state treaty regarding maritime smoke emissions for which the IMO assumed its current authority under conventional international law); UNITED NATIONS OFFICE ON DRUGS \& CRIME (UNODC), ANNUAL REPORT (2014) (the IMO relates to piracy primarily in its efforts to establish an international framework for counter-piracy methods, including judicial mechanisms to punish pirates under international law).

${ }^{4}$ See generally Blockchain in Global Energy Market to Reach USD $11,899 \mathrm{~m}$ by 2024, SAFETY4SEA (July 1, 2019), https: / safety4sea.com/blockchain-in-energy-market-to-reachusd-11899m-by-2024/ (discussing the growth potential of blockchain in the global energy market).

${ }^{5}$ See generally PHILLIP GOSSE, THE HISTORY OF PIRACy (1934).
As nation states developed, so did piracy countermeasures. Thus, pirate activity has fluctuated throughout history; but it has never disappeared. Recently, piracy has emerged as a unique threat to ocean commerce. The nature of modern pirates is notably distinct from that of historical pirates. Modern pirates organize into wellconnected criminal factions, utilize an array of sophisticated methods, and frequently exploit legal, political, environmental, or contractual vulnerabilities. Here, modern pirates are best understood in light of the historical pirates from which they evolved.

\section{History on the Account ${ }^{6}$}

At its start, piracy succeeded through violence and theft, pure criminality labelled by a word referring to belligerent, militant acts: pirata. ${ }^{7}$ In its early practice, piracy is recorded throughout the Mediterranean Sea and surrounding regions. Origins of oceanic settlement record attacks from "sea peoples" in the Aegean and Mediterranean Seas as early as the 14th century B.C., labelling the Phoenicians, Illyrians, and Tyrrhenians some of the first pirates. ${ }^{8}$

One of the earliest thorough records of historical piracy comes from Plutarch, who records a group of pirates that managed, in 75 B.C., to capture Julius Caesar himself. ${ }^{9}$ Seven years later, a fleet of one thousand pirate vessels conquered one hundred cities and invaded Sicilian waters to challenge the Roman Empire. ${ }^{10}$ Two years later, Rome faced a grain shortage caused by pirates' control of the Mediterranean and Black Sea trade routes. ${ }^{11}$ Out of desperation, the Senate granted Pompey, the tactician, full authority over the Seas and those within them, as well as the ability to raise troops, vessels, and equipment. Within three years, Pompey had pushed pirates to the fringe of the Mediterranean. ${ }^{12}$ Though Rome had won, piracy remained

\footnotetext{
${ }^{6}$ See Peter Hayes, Pirates, Privateers and the Contract Theories of Hobbes and Locke, 29 History OF POLITICAL THOUGHT 3, at 461 (2008) (a phrase that bound pirates to commit to a venture until its purpose was attained on account of the obligation codified in the pirates' Articles).

${ }^{7}$ See Samuels, Joel H., How Piracy Has Shaped the Relationship Between American Law and International Law, AM. UNIV. L. REV. 59 (No. 5, June 2010), 1231, 1233 fn 8.

${ }^{8}$ See generally Plutarch, The Parallel Lives: The Life of Pompey, 173 (republished in Loeb Classical Library ed., Vol. V, 1917). See also DAVID CORDINGLY, UNDER THE BLACK FLAG: THE ROMANCE AND REALITY OF LIFE AMONG THE PIRATES 182 (1995) (a crew of "men of desperate fortunes and necessitous of getting vast treasure").

${ }^{9}$ Josiah Osgood, Caesar \& the Pirates: How to Make (and Break) an Ancient Life, 57 Greece \& Rome 319, 319 (2010). After befriending his captors and negotiating his release, Caesar promptly had each pirate crucified. Id at 320.

${ }^{10}$ Plutarch, supra note 9, at 173.

${ }^{11}$ HeNRY A ORMEROD, PIRACY IN THE ANCIENT WORLD 230-34 (1996).

${ }^{12}$ Id.
} 
a tense threat throughout the Mediterranean and the surrounding regions.

At the end of the Renaissance, both piracy and maritime commerce expanded to distant waters - the high seas. ${ }^{13}$ Naval technology developed to foster transcontinental trade and, simultaneously, the far reaches of the ocean became the new pirate stomping grounds. By this time, piracy was criminalized and incorporated into municipal English law, supplying authority to sovereign states under English law to protect their interests by force. ${ }^{14}$ While this was partially successful, piracy continued to exploit valuable cargo by forceful theft wherever possible.

Some nations negotiated with the pirates; others responded with large-scale force. For instance, in 1716, piracy had grown into a lucrative occupation for bandits in the coastal waters of French, Spanish, and English colonies. Based from uncharted, or contested, waters and islands, bandits could avoid one nation's military by bribing another for safe harbor. This period - piracy's Golden Age - is characterized by Bahamian hideaways, Spanish Gold, New England ports, and the profitable slave and sugar trades. Racing to colonize the New World, European nations began granting letters of marque to naval officers, vesting them with enormous resources and vast authority to pursue and punish pirates, enforce judgements of law, and, ultimately, end piracy's "Golden Age" of rampant

${ }^{13}$ J. L. Anderson, Piracy and World History: A Perspective on Maritime Prediation, 6 J. WORLD HIST. 175, 178 (1995).

${ }^{14}$ See GROTIUS, supra note 8 (It was at this time that "pirate," the label first given pirates in Ancient Greece that denoted a "belligerent of war", became defined as a robber on sea that acts outside the purview of the law.).

${ }^{15}$ Theodore Richard, Reconsidering the Letter of Marque: Utilizing Private Security Providers Against Piracy, 39 Pub. Contract L. J. 411 (2010). See Joshua Staub, Letters of Marque: A Short-Term Solution To An Age Old Problem, 40 J. Mar. L. \& Com. 261 (2009) (suggesting that Congress grant letters of marque enabling crews to carry weapons as an interim solution); DAVID J. STARKEY, BRITISH PRIVATEERING ENTERPRISE IN THE EIGHTEENTH CENTURY 20, 21 (1990) (letters of marque were traditionally granted in times of peace to parties seeking "redress [of] a purely private wrong"; privateers were commissioned during war to attack enemies of the crown but were required to split any profits. After the Golden Age, the letters denoted military powers more than a right to restitution).

${ }^{16}$ Colin Woodard, The Republic OF PIRATes 328 (2015) (As stated in the official motto of the Bahamas: "Pirates Expelled, Commerce Restored").

${ }^{17}$ RITCHIE, supra note 9, at 182; see also Richard, supra note 17, at 411 ("Unfortunately, many privateers became pirates" and targeted the same vessels they were once hired to protect."); see also B.S., Bakioglu, The Gray Zone: Networks of Piracy Control $\mathcal{E}$ Resistance, 32 INFO. SOC'Y J. 40 (2016) (Many state powers even found it expedient to sponsor piracy and impede universal sanctions in pursuit of military or financial advantage).

${ }^{18}$ Michael SCOTt MoOre, The Desert AND the SEA 12-13 (2019). plunder. ${ }^{15}$ Within a decade, piracy was reduced to isolated occurrences across open seas, and ocean trade resumed. ${ }^{16}$

After the Golden Age, piracy was nearly dormant. In later years, piracy was recounted by the iconic tales still told today - inflated stories of infamous sailors seduced by the provisions of plunder and a glorious counterculture. ${ }^{17}$ Today, the sad truth is that "the glow of high seas heroism clinging to Pirates of the Caribbean is [nothing more than] Hollywood mistiness and lingering military kitsch" ${ }^{18}$ Still, the piracy plague is an inseparable piece of maritime history stretching from today to antiquity.

\section{Piracy in the Modern Era}

A few decades ago, piracy re-emerged; and, now, it persists. Today's pirates lack any semblance to our iconic tales ${ }^{19}$ of sea-bandits brandishing cutlasses, eyepatches, parrots on the shoulder, or burying chests of treasure. In view of its history, in fact, modern piracy is a novelty.

While less violent than it used to be, maritime piracy today is more sophisticated. Indeed, modern pirates' success depends upon flexible and careful strategy, an understanding of vessel operation, and even the theft of information and equipment. ${ }^{20}$ Modern pirates are organized in criminal syndicates and operate in a sophisticated fashion. ${ }^{21}$ Modern pirates often invest in black markets involved in forgery or arms dealings, and have even fabricated new licenses for stolen vessels. ${ }^{22}$

${ }^{19}$ See, e.g., Woodard, supra note 18, at 325 (Nearly all of the icons in modern portrayals of pirates come from A General History of Pyrates, by Charles Johnson (1724). Recently, after Hollywood's pirate portrayals, the authorship and credibility of the work was widely doubted; indeed, the book "almost single-handedly created the popular images of the pirates that remain with us today.").

${ }^{20}$ See, e.g., Piracy and Armed Robbery, supra note 2, at 11; see also Sarah Percy and Anja Shortland, The Business of Piracy in Somalia, GERMAN INSTITUTE FOR ECONOMIC RESEARCH, 16-17 (2011). https://www.diw.de/documents/publikationen/73/diw_01.c.3 58500.de/dp1033.pdf (Many enterprises are funded by "informal financial exchange channels [including a] pirate stock exchange in the pirate hotspot of Gharadheere"). E.g., 2018 ICC IMB Piracy and Armed Robbery Against Ships - 2018 Annual Report, 11, Table 8: Types of violence to crew, January - December 2014 2018;

https://www.diw.de/documents/publikationen/73/diw_01.c.3 58500.de/dp1033.pdf.

${ }^{21}$ See, e.g., Lisa Otto, The Gulf of Guinea's Troubled Waters: The Evolution of Piracy and Other Maritime Crimes in Nigeria (Nov. 2015) (Ph.D. Dissertation, University of Johannesburg), https:/ /ujcontent.uj.ac.za/vital/access/services/Download/uj:18930/SO URCE1?view=true.

22 Hokey Min, Modern Maritime Piracy in Supply Chain Risk Management, 10 INT. J. LOGISTICS SYS. AND MGMT. 112, 17-18 (2011) ((pirates wait for days at a time and venture quite far from land); see also CHANNEL NEWS ASIA, 2020, Eric Frecon ("in keeping one step ahead of authorities," pirates convene to plan logistics on remote islands); see also Percy and Shortland, supra note 22, at 16. 
Modern piracy "is an organized crime," the success of which "depends on the degree to which [it is] organized effectively." ${ }^{\prime 2}$

Today, the piratical objective is to capture crew, not steal cargo. Using GPS trackers and vessel schematics, pirates locate their target vessel and give chase in a ten-person motorboat. Once they hijack a vessel and kidnap its crew, pirates contact the shipowner to demand a ransom payment in exchange for the safe release of the hostages. With near certainty, each hostage scenario ends with a ransom payment. ${ }^{24}$

Simply put, modern piracy is a game of hostage, ransom, repeat - a business transaction between pirate and shipowner. ${ }^{25}$ The modern practice is a new form of piracy, and it is a profitable one. ${ }^{26}$ In large part due to increasing deployment of innovative anti-piracy mechanisms worldwide, the threat of piracy is now diminishing. Still, it presents an enormous cost to global business. And, still, global regulatory frameworks remain insufficiently scaled to effectively deter piracy across the massive seas in which it occurs. ${ }^{27}$

\section{A WORD ON INSURANCE}

"The marine insurance market is a maze" involving many players with competing interests at stake. To ship-owners, insurance is an indispensable cost of vessel operation. While security mechanisms are partially effective at deterring piracy, maritime insurance is still the best

${ }^{23}$ Global CRIminology: CRIME AND Victimization IN A GLOBALIZED ERA, eds. K. Jaishankar, Nattie Ronel, CRC Press, April 25, 2013, at https://books.google.com/books?id=rcwnAAAAQBAJ\&pg=PT $36 \& l p g=P T 36 \& d q=$ maritime + piracy $+\% 22$ depends + on + the + de gree+to+which+it+is+organized+effectively $\% 22 \&$ source $=b 1 \& 0$ ts $=$ QhIyoMl4Ph\&sig=ACfU3U0m5zQyyc7gqA0bb1GbpfxiwVKXA\&hl=en\&sa=X\&ved=2ahUKEwiwx $-$

i5cbwAhUXQ80KHUxaDesQ6AEwAHoECAMQAw\#v=onepa ge\&q=degree $\% 20$ to $\% 20$ which $\& \mathrm{f}=$ false; see also Martin $\mathrm{N}$. Murphy, Suppression of Piracy and Maritime Terrorism: A Suitable Role for the Navy?, 60 NAVAL WAR COLLEGE REVIEW 23, 25 (2007). See generally PETER T. LEESON, THE INVISIBLE HOOK: THE HIDDEN ECONOMICS OF PIRATES (2009) (Rich history shows organization is essential to piracy success, as demonstrated during the Golden Age in pirate constitutions, kings, investments, and retirement).

${ }^{24}$ Giuseppe Maresca, Fighting Piracy Along the Money Trail, E.U. INST. FOR SEC. STUD. 55, 57 (Oct. 2014) (“[w]ith very few exceptions, no vessel has been released, or crew members liberated, without a ransom being paid."); ONE EARTH FOUNDATION, at 41 (nearly all hijackings end with a negotiated ransom paid in cash and delivered by plane).

${ }^{25}$ Joseph Godfrey, Pirates: and What You Can Do About Them, at 15 (Posted September 17, 2019) https:/ / papers.ssrn.com/sol3/papers.cfm?abstract_id=3452299 modern method of mitigating the expensive hazards of piracy.

\section{Lloyd's of London}

Piracy insurance is largely available through a single provider known as Lloyd's of London ("Lloyd's"). ${ }^{28} \mathrm{~A}$ collection of syndicates that forms the bedrock of maritime insurance, Lloyd's dominates the market as the largest provider of coverage against piracy ("piracy insurance"). ${ }^{29}$ Though it functions as traditional insurance firms do, Lloyd's is far more autonomous.

Brokers at Lloyd's are specialized to insure specific types of risk, and they share information to foster market advantages rather than internal competition. ${ }^{30}$ Lloyd's regulates its own syndicates and participating members by setting rules outlining what is insurable, for what price, and how much capital each syndicate must contribute to insure the liabilities of a policy. Regardless of whether Lloyd's is involved, the process of insuring against piracy is largely the same: coverage is negotiated by underwriters and ship-owners and once brokered, is applied, and interpreted according to the terms of the policy.

\section{The Core Policies}

In general, all ship-owners carry insurance to cover their vessel, its cargo, and the liabilities of the vessel's operation. These categories correspond to the universal types of coverage under three policies that form the core of maritime insurance: Hull \& Machinery ("Hull"), Cargo, and Protection \& Indemnity ("P\&I").

("People just pay the ransoms" and, yet, ransoms often fund illegal activity like terrorism).

${ }^{26}$ INT'L. CHAMB. COMM., Issue Report (2014), https://www.iccccs.org/index.php/piracy-reporting-centre/live-piracy-report (Pirates "became front-page news in 2007 [and, in 2008] took over 40 ships and 700 merchant seamen hostage and ransomed them for many millions of dollars").

${ }^{27}$ Modern piracy operates in waters totaling over one million square nautical miles. See Senate Hrg., infra note 23, at 27.

${ }^{28}$ Christian St. Martin, Piracy \& Terrorism: An Unholy Alliance, 18 LOY. MAR. L.J. 361, 384 (2019).

${ }^{29} \mathrm{Id}$. Lloyd's is not an insurance provider itself, but rather an organized, exclusive market that began as a collection of individuals who pooled capital to underwrite novel ventures with large, unpredictable risks. Each syndicate consists of participating members, who are individuals, partnerships, or corporations that own one-year, renewable memberships in the syndicate and "provide the capital supporting the syndicate's underwriting business". Anja Shortland, Governing Kidnap for Ransom: Lloyd's as a "private regime," 19 (King's College London, 2016). In this way, the syndicates function like an insurance firm.

${ }^{30}$ This information flow is crucial to how the market functions. To price policies and manage claims efficiently, insurers need relevant information from prior cases.

${ }^{31}$ Christian St. Martin, Piracy \& Terrorism: An Unholy Alliance, 18 LOY. MAR. L.J. 361, 382 (2019) (before the three core policies were used, "one policy was used to cover both cargo and vessel"). 
Hull covers damage and loss to vessels caused by perils of the sea, or marine perils, and its coverage is limited to an agreed-upon value that accounts for repairing, salvaging, or investigating a covered damage or loss. Cargo insurance covers the cargo carried by the insured vessel and generally applies on an all-risk basis. ${ }^{32} \mathrm{P} \& \mathrm{I}$ is the broadest form of insurance, serving as a comprehensive coverage of any liabilities arising from vessel operation, including legal damages to third-parties due to pollution, collision, salvage, cargo or on-board injuries. ${ }^{33}$

Together, Hull, Cargo, and P\&I protect against the bulk of the perils of maritime trade. Yet, given the recent growth and unusual circumstances of piracy incidents, piracy coverage is often fraught with concerns to insureds and assureds alike. Coverage issues often invoke the central question: who pays the costs that are not covered by insurance? $?^{34}$

\section{The Coverage of Piracy}

Piracy has been classified as either a risk relating to war (war risk) or a risk relating to sea (marine risk). Thus, it has

${ }^{32}$ See, e.g., Christopher M. Douse, Combating Risk on the High Sea: An Analysis of the Effects of Modern Piratical Acts on the Marine Insurance Industry, 35 TUL. MAR. L.J. 267, 280 (2010). MÜNCHENER RÜCK, MUNICH RE GROUP, Piracy Threat at Sea: A Risk Analysis, 36 (2006). Because cargo insurance relates only to property and is straightforward in application and seamless in its coverage, it is rarely a subject of litigation. Today, pirates hijack vessels to hold the crew hostage and not to steal cargo; thus, the paper will largely ignore the subject of cargo insurance.

${ }^{33}$ V-Group, Marine Insurance Services, Ship Solutions (2020), at https://vgrouplimited.com/insurance/v-scope/ship-solutions. P\&I Clubs provide P\&I policies - groups of shipowners and charterers, usually including both insurers and assureds, who solicit or advertise claims or policies, respectively. Id. Clubs usually do not issue policies, the ship is insured once the Club accepts it. The terms of the liability coverage are specified in the Club Rules, which operate as policy language. There are currently thirteen P\&I Clubs that are members of the International Group of P\&I Clubs, which provides insurance for over $90 \%$ of the world's shipowners. See https:/ /www.igpandi.org/about; Xuelei $\mathrm{Xu}$, Solution to Modern Piracy Issues: From the Perspective of Improving International and Domestic Legal Framework, 141-42, (Jan. 12, 2016) (Ph.D. dissertation, Tulane University) https:/ / digitallibrary.tulane.edu/islandora/object/tulane $\% 3 \mathrm{A5}$ 3443/datastream/PDF/view ("[P\&I coverage as it relates to piracy includes] liability for loss of life injury and illness [and, though] liabilities resulting from war risks are excluded from P\&I Club coverage, piracy is usually exempted from such exclusion. The amount recoverable from a P\&I Club is limited to [what] cannot be recovered from other insurance [sources and coverage of any] ransom payment is subject to the discretion of the club board under sue and labor or omnibus provisions if there is no other indemnity").

${ }^{34}$ See Maritime Piracy and International Trade (2019) Robitaille, https:/ / thelawreviews.co.uk/digital_assets/2a4a5f50-13ae4331-b298-e160babef560/The-Shipping-Law-Review---Ed-6.pdf (most often decided through arbitration, the question is usually between shipowner and charterer). been covered under both Hull and Cargo insurance in recent decades. The coverage has, in fact, repeatedly changed as insurers have shifted between these two classifications: war risk and marine risk. ${ }^{35}$ For the most part, insurers label piracy as a war risk (covered by Cargo) when incidents are frequent and, alternatively, as a marine risk (covered by Hull) when pirate activity is low. ${ }^{36}$

Eventually, however, ambiguity led to the inconsistent application of coverage, prompting insurers to remove "piracy acts" from Hull policies altogether. ${ }^{37}$ Hull policies listed piracy as an "enumerated peril" ${ }^{38}$ alongside risks such as theft, arrest, detainment, and war. Due to the uncertainty as to whether, and which, costs were to be covered, it was cheaper to insure piracy through more specific coverage that was narrowed to fewer potential incidents. ${ }^{39}$ So, piracy coverage moved to kidnap and ransom policies ("K\&R"), a new form of insurance that covered piracy as a war risk, and which now constitutes nearly the entire scope of insurance for piracy-related costs. ${ }^{40}$

${ }^{35}$ See generally Richard L. Kilpatrick Jr., The 'Refugee Clause' for Commercial Shipping Contracts, 46 GA. J. INT'L \& COMPAR. LAW, 403-46 (2018) https:/ / ssrn.com/abstract=3508372.

${ }^{36}$ Sec. 2-9, Norwegian Marine Insurance Plan of 1996 (2010).

${ }^{37}$ Robert T. Lemon II, Allocation of Marine Risks: An Overview of the Marine Insurance Package, 81 TUL. L. REV. 1467, 1470 (2007). See Peter Hallin, Threat of Piracy: Hire Issues in Time Charterparties, 13-15 (2010) (Master Thesis, University of Lund). Since 2006 Lloyd's has covered incidents of piracy and terrorism under machine and hull or, specifically, marine hull war risks. Lloyd's News Centre, March 2006, https:/ /www.lloyds.com/news-andrisk-insight; Insurance Journal, 20 March 2006 http:/ / www.insurancejournal.com/news/international/2006/0 3/20/66594.html. Since 2006, Hull covers piracy risk under the Institute Time Clauses 1/10/83. Martin N. Murphy (2006) 148, 114. Lloyd's News Centre, https://www.lloyds.com/news-andrisk-insight; Insurance Journal, 20 March 2006 http:/ /www.insurancejournal.com/news/international/2006/0 3/20/66594.html.

${ }^{38}$ Enumerated perils must proximately cause damage or loss to the vessel for coverage to apply. See Robert T. Lemon II, Allocation of Marine Risks: An Overview of the Marine Insurance Package, 81 TUL. L. REV. 1467, 1468 (2007).

${ }^{39}$ Anja Shortland, Governing Kidnap for Ransom: Lloyd's as a "Private

Regime," 15 (King's College London) (2016). "Given the transaction costs of enforcing contracted ransom negotiations, the Coasean prediction would support a single supplier." For instance, "there are high information costs in verifying whether a 'premium' ransom was paid [and, further], cheating can occur without detection [and contracting is] neither enforceable nor selfenforcing [...] in presence of high transactions costs, externalities can be completely internalized by one firm owning all the activities that have external effects on each other".

${ }^{40} \mathrm{~K} \& \mathrm{R}$ policies, often known as riders, "rode on" to a larger core policy - most often Hull - such that the covered risk was still classified as a peril of the sea or marine risk. $K \& R$ riders did not begin to appear in large numbers until 2008, the peak year of 
In essence, $K \& R$ policies are unique creations prompted by the shortcomings of prior maritime insurance against piracy. ${ }^{41}$ Compared to prior policies, K\&R contains fewer limitations that make coverage uncertain. ${ }^{42} \mathrm{~K} \& \mathrm{R}$ covers liabilities arising from a piracy incident, including the delivery and payment of ransom, negotiation, lost wages, counseling services and other expenses of crisis response. ${ }^{43}$ K\&R policies typically do not contain deductibles because premiums mainly accrue to cover future claims. Yet, premiums are notoriously steep. ${ }^{44}$

To minimize extortion and maximize bargaining power, K\&R providers require strict secrecy as a condition of coverage that, if violated, may void a policy. In most cases,

piracy incidents. For instance, K\&R indefinitely stripped piracy of Hull coverage as a marine risk and, although most favor $K \& R$ coverage to any other, piracy can still be shifted back to Hull by specifically including it as an enumerated peril once again. See, e.g., Christopher M. Douse, Combating Risk on the High Sea: An Analysis of the Effects of Modern Piratical Acts on the Marine Insurance Industry, 35 TUL. MAR. L.J. 267, 286 (2010); Peter Hallin, Threat of Piracy: Hire Issues in Time Charter-parties, University of Lund, MARITIME LAW, 61 (Thesis, 2010) ("[p]iracy should be (and is in most cases) considered a war risk. The flexibility of the K\&R insurance (e.g. with movable trading limits) makes it more apt to handle piracy").

${ }^{41}$ Christian St. Martin, Piracy and Terrorism: An Unholy Alliance, 18 LOY. MAR. L.J. 361, 382 (2019).

${ }^{42}$ Xuelei $\mathrm{Xu}$, Solution to Modern Piracy Issues: From the Perspective of Improving International and Domestic Legal Framework, 143, (Jan. 12, 2016) (Ph.D. dissertation, Tulane University)

https:/ /digitallibrary.tulane.edu/islandora/object/tulane \%3A5 $3443 /$ datastream/PDF/view. Surge in piracy prompts demand for K\&R cover, Lloyd's News and Insight, (28 Oct 2008), http:/ / www.lloyds.com/news-and-insight/news-and-

features/archive/2008/10/surge_in_piracy_prompts_demand_f or_broader_cover_28102008. Id.

${ }^{43}$ Since 2008, kidnap insurance is underwritten or reinsured at Lloyd's. Providing all K\&R policies, approximately twenty "specialty risk" syndicates operating out of the same floor, sharing profit and information, and collectively bearing the liabilities of each K\&R policy. See Jeff Spross, The Weird World of Kidnapping Insurance, THE WEEK (MEDIA, 2019), (the specialty risk syndicates insure a combined $\$ 1.5$ billion worldwide, totaling $\$ 250$ to $\$ 300$ million annual insurance.);

Vivienne Walt, Why the Somali Pirates Keep Getting Their Ransoms, TIME MAG. (Apr. 20, 2009) http:/ / content.time.com/time/world/article/0,8599,1892366,00. html (Hiscox Insurance Co Ltd. in London writes about two thirds of the world's K\&R insurance policies); See also Grant Smith, Why Strait of Hormuz is the World's Oil Flashing Point, (BLOOMBERG, 2019) ("To effectively participate in the K\&R market, an insurer needs to gain entry to the club, both by contributing capital and by complying with its rules.").

${ }^{44}$ See infra, Section IV, Counting the Cost of Countering Piracy.

${ }^{45}$ See Kharchenko, at 36. (disclosure of K\&R policy ownership is often authorized solely for $K \& R$ insurers for the purpose of premium discounts); Edward Ion, Kidnap and Ransom-the Shipping Industry Nightmare, June 2016, only a handful of individuals are privy to a policy's existence. ${ }^{45}$ However, information scarcity is a recurring problem. Insufficient data creates substantial uncertainty of market factors such as premium prices, coverage limits, and claim frequency; thus, predicting rates is difficult. (Some suggest that K\&R will grow more expensive and less common as a result. $)^{46}$

Though they are the preferred medium of piracy insurance due to their clarity and pricing, ${ }^{47} \mathrm{~K} \& \mathrm{R}$ policyholders deemed to bear increased risk of seizure by pirates - are required to notify their insurer before sailing a vessel into

newsletter--june-2016/kidnap-and-ransom-the-shippingindustry-nightmare (discussing a K\&R policy or even referencing its existence can terminate the policy since those with $K \& R$ cover are then more attractive hijacking targets); Kidnap and Ransom Insurance: At an Inflection Point, COGNIZANT.COM, October 2015, https://www.cognizant.com/whitepapers/Kidnap-and-

Ransom-Insurance-At-an-Inflection-Point-codex1575.pdf. The claims ratio for $K \& R$ insurance is $35 \%$ according to some calculations, nearly half the commercial standard (70\%). Id. https: / / www.tandfonline.com/doi/full/10.1080/10192557.2020 .1717037? casa_token $=\mathrm{y}$ -

lmMflk2QAAAAAA\%3A_pW70UEzRoikGcAHmDVMrVLEyg3 3QCT6OOE_VTlgcyyu6n6xVzFbOrmi5PiEmufZYzeaTIo5Qkfgg uM. (2019) (“[b]ecause companies' fears of increased insurance premiums, authorities' fear of being put back on the map as a pirate destination, insiders' interest in keeping it quiet [to] get their own cut of the profits [incidents are kept private]").

${ }^{46}$ Anja Shortland, Governing Kidnap for Ransom: Lloyd's as a "Private

Regime," 18 (King's College London) (2016). Kai Ryssdal et al., The Economics of Kidnapping, WESA (Apr. 30, 2019) https://www.wesa.fm/post/economics-kidnapping\#stream/0.

See Jeff Spross, The Weird World of Kidnapping Insurance, THE WEEK (MEDIA, 2019). As the primary reinsurance market, then, it is likely that any given insurance of a substantial risk that is "written on a direct basis has a reasonable chance of being reinsured or retroceded back into the Lloyd's market." (A list compiled from interviews of brokers at Lloyd's in 2015 compiled by Anja Shorthand showed that, with one exception, K\&R risks are underwritten by a syndicate at Lloyd's or brokered by Lloyd's brokers.); Menghie Jin et al., Marine Piracy Prediction and Prevention: Policy Implications, Marine Policy 108 (2019), (“OBP estimates that, in 2017, 35\% of ships carried K/R insurance totaling \$20.7 million").

${ }^{47}$ Dorota Jolanta Chmielewska, The Increased Risk of Piracy Presenting New Challenges For Marine Insurance Market 54 (June 8, 2011) (unpublished Master thesis, Lund University) (on file with the Master Programme in Maritime Law); See Laura L. Hardy, Ordering Chaos at Sea: Preparing for Somali Pirate Attacks through Pragmatic Insurance Policies, 55 St. Louis U. L.J. 665, 680 (2011) ("[e]xempting war risks from Hull coverage makes sense in terms of allocating risk [as the] vessels that are traveling a safer route, or who choose to take on the risk of piracy[,] do not have to pay the additional premium for [that particular] coverage [and, thus] liability for piracy is spread between the appropriate parties"). 
a high-risk area ("HRA"). ${ }^{48}$ (HRAs are nautical zones whose boundaries are established by Lloyd's Joint War Committee ("JWC").) ${ }^{49}$ At that time, the policies provide the underwriters an opportunity to amend the terms before granting permission, or to terminate the policy completely. ${ }^{50}$ Entry into an HRA automatically incurs a supplementary charge payable by the shipowner ${ }^{51}$ to cover any potential claims due to re-routing, hijacking, or extra security expenses. ${ }^{52}$

Defining HRA boundaries - and pricing the policies that cover insured vessels within those boundaries - is an

48 See War risks QEA, the MECO group, https://www.themecogroup.co.uk/charterers-liabilityinsurance/wp-content/uploads/sites/2/kalins-

pdf/singles/war-risks-qa-june-2019.pdf (According to the standard clauses, such as standard charter-parties BIMCO CONWARTIME 1993/2004; BALTIME 1939/2001); VOYWAR 1993/2004); See BIMCO CONWARTIME 2013, Clause (d); War Risks Policy (Form No. 3S), Article 1 (20016) (identifies perils that, like piracy, are covered as a risk of war rather than other common marine risks); But see Exclusion Clause 13, Section 14, 2019 Terms \& Conditions https://www.themecogroup.co.uk/charterersliability-insurance/wp-content/uploads/sites/2/kalins$\mathrm{pdf} /$ singles/war-risks-qa-june-2019.pdf (if a vessel or cargo is damaged due to a peril named in the aforementioned exclusion clause, such as a missile or an obstruction of the insured vessel's rightful ability to discharge at a named location - constituting an act of war - then damage or loss resulting from such act(s) would not be covered by, but can be reinstated against, an additional premium payable by the shipping interest). See also Rajinder Kumar, Strengthening seafarers' rights for release and repatriation: piracy in the Gulf of Guinea 46 (Nov. 3, 2019) (unpublished Masters dissertation, World Maritime University Dissertations) (on file with World Maritime University Library).

("[w]hile an owner carries the burden of normal insurance risks; it is common practice for additional premiums incurred for $K \& R$ insurance cover to be allocated to the charterer")

${ }^{49}$ Boundaries of HRAs usually overlap those of HRAs and, in many circumstances, are essentially redundant. See, e.g., Dr. Shikha Basnet \& Anna Bowden, One Earth Future Foundation, The Economic Cost of Somali Piracy 14 (2011) (working paper) (published by OCEANS BEYOND PIRACY ORG.), http:/ / oceansbeyondpiracy.org/sites/default/files/attachment s/ECOP\%20Full\%20Report\%202011.pdf ("[K\&R] premiums may be reduced if ships have armed security guards, or other security equipment [although BMP compliance] is usually expected as standard and may be a requirement of underwriting.").

${ }^{50}$ LUIS LOBO-GUERRERO, INSURING WAR: SOVEREIGNTY, SECURITY \& RISK 108 (2012).

${ }^{51}$ Or, more specifically, the freight payor - the party paying for the carriage of cargo.

52 Aytac Akgul, More Than Shipping (2019), https:/ / www.morethanshipping.com/what-is-the-war-risksurcharge/ (discussing that Maersk and Hapag-Lloyd added record-breaking War risks Surcharges for shipments through the Arabian Gulf after there had been six tanker attacks in that region in the past two months - increased charges on cargoes headed for the Middle East totaling $\$ 42$ per twenty foot equivalent unit - the added cost is easily $\$ 100,000$ per year). enormous responsibility. ${ }^{53}$ Though this responsibility is shouldered almost entirely by the commercial sector, an HRA is routinely described as a "political, legal and security experiment [and a] zone of exception [where] special precautions should be taken by the shipping industry as a whole." ${ }^{54}$ Underwriters draft the scope of coverage by "delineating worldwide geographic areas where [coverage applies within defined] navigation limits." ${ }^{55}$

Accordingly, underwriters assess each voyage based upon the undisclosed amount of risk that they perceive from an

${ }^{53}$ David Anderson et al, Somalia and the Pirates 33 (European Security Forum, Working Paper No. 33, 2009), http:/ / aei.pitt.edu/14447/1/ESF_WP33_ANDERSON_EDIT_So malia_and_the_Pirates_e-version.pdf(Lloyds removes the waters of the Malacca Strait from its listed classification as an HRA after piracy incidents began to decrease); The Lloyd's list podcast: Piracy In the Time of the Coronavirus, MARITIME INTELLIGENCE (Apr. 3, 2020),

https:/ /loydslist.maritimeintelligence.informa.com/LL1131816 /The-Lloyds-List-Podcast-Piracy-in-a-time-of-coronavirus; Great Cost of Piracy at Over US $\$ 800$ Million, MARITIME FAIRTRADE (Dec. 30, 2019), https:/ / maritimefairtrade.org/great-cost-of-piracy-atover-us800-million/; Menghie Jin \& Wenming Shi, et al., Marine Piracy Prediction and Prevention: Policy Implications, MARINE POLICY, 108 (2019) 103528; Transcript of Statement by Senior Minister of State, Ministry of Defence and Ministry of Foreign Affairs Dr Mohamad Maliki bin Osman at the 19th Indian Ocean Rim Ass'n (IORA) Council of Ministers Meeting, 7 November 2019 (addressing collective responsibility of littoral states and affirming published research, https:/ / www.mfa.gov.sg/Newsroom/Press-Statements-

Transcripts-and-Photos/2019/11/071119_SMS-IORA-Transcript, and WORLD POLITICS REVIEW, online article, West Africa Gulf of Guinea Piracy is a Growing Threat, at https:/ / www.worldpoliticsreview.com/articles/28824/in-westafrica-s-gulf-of-guinea-piracy-is-a-growing-threat, (IMB's substantial concern over "unprecedented rise in kidnappings" in 2019, a statistical confirmation of the dire need for "increased information exchange and coordination between vessels [in order to] accurately highlight the high-risk areas [that have been] persistently vulnerable waters"); See Sam Meredith, Insurance rates have 'increased 10-fold' after attacks in the Strait of Hormuz, shipping CEO says, CNBC (Jul. 9, 2019, 7:41 AM), https://www.cnbc.com/2019/07/09/oil-insurance-rates-havesoared-since-tanker-attacks-near-iran.html (stating breach premiums are triggered when a vessel enters an HRA, computed based on the value of the hull of each specific vessel).

${ }^{54}$ Christian Bueger, Lessons from the Debate on the High-Risk Area (Oct 9, 2015) (on file with Lessons From Privacy), http:/ / www.lessonsfrompiracy.net/2015/10/09/the-high-riskarea-debate-what-was-at-stake/, Cardiff University (2015).

${ }^{55}$ Christopher M. Douse, Combating Risk on the High Sea: An Analysis of the Effects of Modern Piratical Acts on the Marine Insurance Industry, 35 TUL. MAR. L.J. 267 (2010); See

(Supertankers transiting the Gulf of Aden/Asia route earn freight rates of approximately $\$ 42,000$ per day and, yet, K\&R premiums are almost equal to what they make in total freight); Anna Bowden, The Economic Costs of Maritime Piracy (December 2010) 
individual assessment of a vessel's size, speed, and weight. $^{56}$

Current disputes over the HRA are related to a debate between the JWC and the United Nations Security Council $^{57}$, on the one hand, and the coastal states, on the other. The debate concerns the issue of who has authority to establish HRAs, and by what method(s). After all, HRAs were made to be "self-regulating devices, not legal states. Yet, they achieved semi- statehood, perhaps by virtue of being referenced so [by] domestic regulations and counterpiracy legislations." ${ }^{\prime \prime 8}$

Due to the unpredictability of piracy risk, the JWC makes recommendations to the insurance underwriters "based on evidence it considers relevant [and largely] relies on the judgement of committee members influenced by [reference to] external security consultant[s]". ${ }^{59}$ Those involved in its creation have described the process as a "London-based black box", implicating that the factors used to assess risk are only available to ship-owners. ${ }^{60}$

(working paper) (on file with One Earth Future) (premiums were $\$ 150,000$ per ship).

${ }^{56}$ See Piracy on the High Seas: Protecting out Ships, Crews \& Passengers Before the Subcommittee on Surface Transportation \& Merchant Marine Infrastructure, Safety and Security of the Committee on Commerce, Science \& Transportation, U.S. Senate, 111th Congress 1st Session (2009) (supposedly, higher speed and lower freeboard are the sole qualities that, if present to some extent, are capable of earning the insured vessel premium discounts from the reduction in risk they represent, according to the underwriters' calculations. In fact, there is ample evidence that these two factors, far more than any other, are most dispositive of whether or not a particular vessel is at risk of being successfully boarded by pirates).

${ }^{57}$ See Glenn H. ReYNOlds \& ROBERT P. MERges, OUter SPACE: PROBlems OF LAW \& POLICY 8, Westview Press (2d ed. 1997) (stating that the same entity that in the late 1950's along with the United Nations' General Assembly and the Committee on the Peaceful Uses of Outer Space, was involved in negotiated legislating and public discourse that led to the Outer Space Treaty).

${ }^{58}$ The HRA creation was an inadvertent conflation of different areas of counter-piracy investment and regulatory safety operations by both public and private entities from numerous sovereign states. The result was a tangled mess of various zones established by various industries for various purposes in waters near various littoral states. Specifically, in a December 2020 meeting of the UN Security Council in relation to S/res/2516 (2020). See S.C. Res. 2500, II 3 (Dec. 4, 2019) (where the Council reaffirmed the UNCLOS definition of the international criminal act of piracy, which is adopted by far more sovereign states than any other definition and which controls much of the piracy litigation as well as the commercial contracting against the risks of piracy; the Council's continued reaffirmation solidifies the normative legality of UNCLOS' definition of piracy).

${ }^{59}$ See Miha Hribernik, Countering Maritime Piracy and Robbery in Southeast Asia: The Role of the ReCAAP Agreement (European Inst. for Asian Studies, Briefing Paper 2013/2)

\section{Counting the Cost of Countering Piracy}

Modern piracy is a monetary threat best handled by insurance mechanisms. Yet, mitigating piracy is a substantial global expense that is computable and manageable, but not preventable. The profits of piracy, in fact, are a mere fraction of the global costs produced by piracy. Data regarding such costs is imprecise, however, as many incidents are unreported or reported inaccurately. ${ }^{61}$ However, due in large part to the research of international organizations and academic institutions, there is some reliable data.

Overall, maritime piracy has caused global trade costs to increase by at least $\$ 15$ billion each year, including expenses such as ransom payments and related services, vessel defense, extra fuel consumption, and foregone trade. $^{62}$ Ransom payments are estimated to have been as high as $\$ 15$ million per vessel - \$200,000 in 2005, \$500,000 in 2007, and $\$ 4$ million in 2011 (pirates' most lucrative year). ${ }^{63}$

${ }^{60}$ See Bueger, supra note 58, at 3; See also Piracy on the High Seas, supra note 60.

${ }^{61}$ MÜNCHENER RÜCK, MUNICH RE GROUP, Piracy Threat at Sea: A Risk Analysis, 17 (2006) (stating IMB estimates that more than half of piracy attacks go unreported; nonetheless, the number of piracy incidents increased rapidly in the late 2000s and peaked in 2011, when there were over 400 occurrences of piracy); See, e.g., Bowden, supra note 59.

${ }^{62}$ Bowden, supra note 59 (estimating \$7-12 billion); Sami Bensassi \& Inmaculada Martínez-Zarzoso, How Costly is Modern Maritime Piracy to the International Community? Review of International Economics, IBERO-AMERIKA INSTITUT FÜR WIRTSCHAFTSFORSCHUNG

INSTITUTO IBERO-AMERICANO DE INVESTIGACIONES ECONÓMICAS IBERO-AMERICA INSTITUTE FOR ECONOMIC RESEARCH, 20 (2012) (stating costs from international trade loss is $\$ 28$ billion); Basnet, supra note 53.

${ }^{63}$ REvIEW Oct. 4, 2019, http://www.marsecreview.com/wpcontent/uploads/2010/10/Piracy-Report-v6.pdf; Ransom money laundered by pirates affects stability in the Horn of Africa, says UNODC chief, UNITED NATIONS: OFFICE ON DRUGS AND CRIME (Feb. 22, 2012),

https://www.unodc.org/unodc/en/frontpage/2012/February / ransom-money-being-laundered-by-pirates-affects-stability-inthe-horn-of-africa-says-unodc-chief.html (the most lucrative year for pirates was 2011, when they collected about $\$ 170$ million; But see Basnet, supra note 53 (proving other studies have produced larger figures such as \$5.4 million apiece in 2011); See also Pirate Trails: Tracking the Illicit Financial Flows from Pirate Activities off the Horn of Africa WORLD BANK (2013),

https://www.imolin.org/pdf/imolin/piracy/Pirate_Trials.pdf; Konstantinos Kattides, The Impact of Piracy on Marine Insurance (Feb. 2013) (unpublished paper) (on file with Cyprus University of

Technology), https:/ / www.academia.edu/6809890/Analyse_th e_impact_of_piracy_on_marine_insurance. $C f$., ICC COMMERCIAL CRIME SERVICES, https://www.icc-ccs.org/index.php/piracy- 
Each ransom payment includes costs for its delivery and negotiation, as well as crisis management services. ${ }^{64}$ As the average negotiation lasts six months, paying a ransom can often cost a shipowner three times the amount of the actual payment due to related costs. ${ }^{65}$ However, by far the largest cost of piracy - about half of the total costs - is the expense of extra fuel consumed by navigating a vessel farther and/or faster than is optimal in order to avoid piracy threats. ${ }^{66}$

Over the past decade, piracy has been declining. The result is due, in part, to increased compliance with safety guidelines and the development of vessel defense mechanisms. ${ }^{67}$ The IMO's shipowner guidelines - "Best Management Practices" - detail ideal vessel management practices which encourage the use of barbed wire and long-range acoustic devices, for instance. Although many

reporting-centre/prone-areas-and-warnings (zero incidents in the first four months of 2020).

${ }^{64}$ In 2018, ransom-associated costs totaled $\$ 350$ million. Jonathan Bellish, The Economic Cost of Somali Piracy 2012 43, 1 (2012) (working paper) (published by OCEANS BEYOND PIRACY ORG.), http:/oceansbeyondpiracy.org/sites/default/files/ecop2012fina 1_2.pdf ("Between 2011 and 2012, the number of attempts and hijackings fell much more drastically than the cost of combatting piracy. This led to a substantial increase in the 'per incident cost of piracy. In 2011, each pirate attack cost \$28.6 million, and in 2012 , that number rose to $\$ 82.7$ million."). See generally IMO ANNUAL REPORT (2018) (the effect on US markets from laundered ransom money leaving Somalia - estimated at $40 \%$ of every ransom - funds institutions and activity that could be detrimental to US trade, transport, and military). Cf., THE FINANCIAL ACTION TASK FORCE (FATF), Organized Maritime Piracy and Related Kidnap for Ransom, FATF Report, 7-8 (2011) ("Ransoms are rising exponentially, from an average of $\$ 150,000$ per ransom in 2005 to $\$ 5.2$ million per ransom in 2010").

${ }^{65}$ Given the off-hire obligations of each idle vessel's charterer, an idle vessel accrues interest at the same rate as do ransom payments, which likely determines the duration, outcome, and terms of the ransom. Without citing data that would surely reflect reality poorly since many hijackings are never reported publicly, idling costs in the neighborhood of $\$ 5$ million per year, based on the author's general knowledge.

66 COMPASS MARITIME WEEKLY REPORT (2019), HTTP: / / WWW.COMPASSMAR.COM/REPORTS/COMPASS\%20MARITI ME\%20WEEKLY\%20MARKET\%20REPORT.PDF (Stating for large carrying vessels, extra fuel consumption alone can cost shipowners $\$ 20,000$ per day).

67 See Stella Sakellaridou, Maritime Insurance \& Piracy 16 (September 2009) (on file with Assoc. Internacionale de Droit des Assurances (AIDA) at Nat'1 \& Kapodistrian Univ. of Athens' L. Sch.),

http:/ / www.aida.org.uk/AIDAEurop/AIDAStellaspaper.pdf. (International collaboration has compiled an arsenal of piracydeterrence mechanisms).

Recent developments include long range acoustic devices capable of projecting fire alarm-like sounds at 900 decibels at moving targets hundreds of meters away, barbed wire fences, sandbags, saferooms, floodlights, naval deployments, an electric fence called "Secure-Ship" that delivers a 9000-volt shock and private guards of the mechanisms have proven to be ineffective against pirate hijackings, private security companies will successfully protect a vessel for $\$ 50,000$ per transit. ${ }^{68}$ However, crossing the high seas with guns is complicated - it raises legal and diplomatic issues whether due to an armed conflict or the permissible entry of armed foreigners securing a trans-oceanic vessel that enters a nation's territorial waters. ${ }^{69}$

Private security guards may exercise lethal force when approached by another vessel. However, the use of lethal force against pirates is not explicitly permitted by UNCLOS. ${ }^{70}$ Thus, current debate centers on who should regulate such action, and how, if at all. ${ }^{71}$ Unlike protecting a sovereign state, the scope of private security force used to defend a vessel against pirates is unclear. ${ }^{72}$ Many states

utilized by one quarter of vessels in HRA-transit despite controversy and uncertainty).

${ }^{68}$ E.g., Raymond Gilpin, Counting the Cost of Somali Piracy 126 (United States Inst. of Peace, Working Paper No. 1, (2009), http:/ / www.bowman.co.za/FileBrowser/ArticleDocuments/C ountingtheCostofPiracy_1.pdf (onboard deterrents are little more than a quick fix; anti-piracy defenses do not seem to fix the problem); Min, supra note, 24 at 126 (stating that insurance premiums for vessels crossing the Gulf were $\$ 500$ in 2007. In 2008 they had increased to $\$ 20,000$ per transit; still, in 2011 ships paid $\$ 25,000$ in premiums per transit as hiring guards is still more expensive).

${ }^{69}$ Piracy on the High Seas supra note 60 (stating that according to Captain Phillips, "[t]here is an 1819 statute which permits vessels to defend themselves. [Yet,] a subsequent State Department arms regulation" requires a license for any abroad passage of a firearm which, upon entrance in any other State's port, further mandates receipt of a certificate prior to, and establishing the legality of, importing the weapon(s) into each respective State.") According to Captain Phillips, "[t]here is an 1819 statute which permits vessels to defend themselves. [Yet,] a subsequent State Department arms regulation" requires a license for any abroad passage of a firearm which, upon entrance in any other State's port, further mandates receipt of a certificate prior to, and establishing the legality of, importing the weapon(s) into each respective State." Piracy on the High Seas: Protecting out Ships, Crews \& Passengers Before the Subcommittee on Surface Transportation \& Merchant Marine Infrastructure, Safety \& Security of the Committee on Commerce, Science \& Transportation, 111th Congress 1st Session (2009).

${ }^{70}$ See infra, notes 90-91.

${ }^{71}$ Int'l Law Comm'n, Rep. on the Work of Its Seventy-First Session, U.N. Doc A/74/10, annex C (Aug. 20, 2019) (explaining that while not permissible under UNCLOS, it is neither forbidden by normative practice nor by the laws of the member states to exercise lethal action but rather the question involves asking whether PSC force should be regulated by imposing flag state regulation, or whether it should be regulated by the flag state directly, or whether it should be regulated by other states).

${ }^{72}$ Bueger, supra note 58, at 8-9 (discussing how "the BMP are the basis of cooperation for a broad range of actors and provide a strategic narrative" and arguing for the assimilation of weapons, guards, and armed conflict into the law of each guarded vessel's flag state). 
deem ships with private security as hostile vessels and, accordingly, preclude the use of private security guards on any vessel under that state's control. ${ }^{73}$ Faced with the "real world [of] aggressive pirates the [shipping] industry has simply dealt with the unknowns [by citing] the simple fact [that] '[n]o ship with armed guards has [ever] been taken by pirates'." ${ }^{74}$ Still, many vessels navigating pirate-prone waters choose not to employ private security. ${ }^{75}$

From 2008 to 2010, K\&R surcharges ("premiums") for entering an HRA increased from $\$ 500$ per vessel-voyage, to $\$ 150,000$ per vessel-voyage. ${ }^{76}$ The surge in premiums followed the JWC's decision to label the Strait of Hormuz and Gulf of Oman as HRA waters. ${ }^{77}$

Even more significantly, in 2008 - the year that piracy risk was at an all-time peak - premiums increased from $\$ 500$ to $\$ 25,000$ per transit. ${ }^{78}$ In fact, premiums are predicted to

${ }^{73}$ See, e.g., Lawrence J. Kahn, Pirates, Rovers and Thieves: New Problems with an Old Enemy, 20 TUL. MAR. L. J. 293, 317 (1996) (carrying firearms for protection on any private vessel is strongly discouraged by the British Crown); cf. Thomas J.R. Stadnik, Esq., Pirates: Common Enemies of All, the Enemies of the Human Race, the Law of War, and the Rule of Law, LEXISNEXIS LEGAL NEWS ROOM (May

5 ,

2009),

https://www.lexisnexis.com/legalnewsroom/international-

law/b/international-law-blog/posts/pirates-_2d00_-the-

common-enemies-of-all_2c00_-the-enemies-of-the-human-

race_2c00_the-law-of-war-and-the-rule-of-law. Andrei

Kharchenko, Piracy: Recent Trends on Insurance and Chartering

Market, AMERICAN B. ASS'N, 2015, at 25-26 (explaining that private security contracts give the guards full authority over the use of force, creating a rare limitation on the executive authority given to a captain by customary law).

${ }^{74}$ David Isenberg, The Rise of Private Maritime Security Companies, CATO INST. (May 26, 2012), https:/ / www.cato.org/publications/commentary/rise-privatemaritime-security-companies.

${ }^{75}$ See generally Rawle O. King, Ocean Piracy and Its Impact on Insurance, 2 CURRENT POL. \& ECON. AFR. 363 (2010).

${ }^{76}$ E.g., Sarah-Letetia Craze, Piracy as a Manifestation of State Failure: A Historical Context for Somali Piracy and Its Suppression, Political Science Dissertation (2018), at https:/ / www.semanticscholar.org/paper/Piracy-as-amanifestation-of-state-failure\%3A-a-for-

Craze/afe8e8a24bd4a0b88473418752a8bd719366d20a;

Berg/Artmann/Kratz u.a., Münchener Rück, Piraterie - Neue Dimension, S. 6." International Maritime Bureau, Piracy Report 2009, S. 12; Carolyn Bandel, Kevin Crowley, Somali Pirate Attacks Sink Premiums After Insurers Leap Aboard, BLOOMBERG BUSINESS ONLINE (August 2, 2010), at https: / /www.bloomberg.com/news/articles/2010-08-

02/ somali-piracy-attacks-surge-premiums-sink-as-moreinsurers-leap-aboard.

${ }^{77}$ See Gabriel Olano, Marine insurers charge war risks premiums after port attacks, INS. BUS. MAG. (June 4, 2019), https:/ /www.insurancebusinessmag.com/asia/news/marine/ marine-insurers-charge-war-risk-premiums-after-port-attacks168945.aspx (illustrating that the increased premiums were likely due to attacks on tankers in the Arabian Gulf). comprise a market consisting of over $\$ 4$ billion in annual revenues. ${ }^{79}$ Under $\mathrm{K} \& \mathrm{R}$, piracy insurance limits are at least \$15 million, although according to the Swedish Club' 2018 Circular, they could be as high as $\$ 75$ million. ${ }^{80}$

Today, paying higher insurance premiums is the norm. ${ }^{81}$ In most instances, shipowners can afford the costs of coverage, as steep as they may be. Ultimately, however, there is not much of a choice. It is out of the question to operate a vessel in international waters without insurance against piracy.

Yet, the world lacks fundamental information to posture a reliable estimate of Lloyd's risk calculations. Likely one half of piracy incidents - perhaps far more - are hidden from public view by insurer and insured alike. ${ }^{82}$ Still, the hidden market is lucrative: the piracy insurance market, in total, has been valued at $\$ 900$ million. $^{83}$

${ }^{78}$ See NEW YORK TIMES, online article, Surge in Piracy Raises Concern Over Maritime Terrorism (Nov. 25, 2008), at https://www.nytimes.com/2008/11/25/world/asia/25iht-

pirates.1.18133159.html ("[t]he corporate security firm BGN Risk estimates that the special risks insurance levy for crossing the Gulf of Aden [in 2008] leapt to $\$ 20,000$ per vessel per transit from $\left.\$ 500^{\prime \prime}\right)$.

${ }^{79}$ Xuelei Xu, Solution to Modern Piracy Issues: From the Perspective of Improving International and Domestic Legal Framework, TUL. U. SCH. L., Jan. 12, 2016, at 47, https:/ /digitallibrary.tulane.edu/islandora/object/tulane $\% 3 \mathrm{A5}$ 3443/datastream/PDF/view.

${ }^{80}$ See Rajinder Kumar, strengthening seafarers' rights for release and repatriation: piracy in the Gulf of Guinea, WORLD MAR. U., Nov. 3, 2019, at

https: / / commons.wmu.se / cgi/ viewcontent.cgi?article=2210\&co ntext=all_dissertations; see generally U.N. Secretary General, Report of the Secretary-General on the situation with respect to piracy and armed robbery at sea off the coast of Somalia, U.N. Doc. S/2013/623, at 10-11 (Oct. 21, 2013).

${ }^{81}$ See Freedom C. Onuoha, Piracy and Maritime Security in the Gulf of New Guinea: Trends, Concerns, and Propositions, 4 J. Middle East \& Afr. 267, 289 (2013); but see Report of the Maritime Safety Committee on its 101st Session, MSC 101/24, at 71, 74 (July 12, 2019) (" $\mathrm{t}]$ he Committee considered document MSC 101/18/1 (ICS et. al.), providing information on the decisions by the industry group related to the review and revision of HRA to amend the geographic boundaries and to reduce the area to better reflect the threat of piracy in the region.").

${ }^{82}$ See, e.g., GERBEN J.N. BRUINSMA \& SHANE D. JOHNSON, THE OXFORD HANDBOOK OF ENVIRONMENTAL CRIMINOLOGY 918 (2018); cf. Int'l Mar. Org. [IMO], Piracy and Armed Robbery Against Ships, MSC.1/Circ.1334, annex at 15-16 (June 23, 2009) (illustrating that guidance instructs, and in the case of insurance, obligates, that all attacks be reported to the IMB); see generally Small Arms Survey 2012: Moving Targets, SMALL ARMS SURVEY, at 195 (2012), http:/ / www.smallarmssurvey.org/fileadmin/docs/A-

Yearbook/2012/eng/Small-Arms-Survey-2012-Chapter-06EN.pdf.

${ }^{83}$ See U.N. Conference on Trade and Development, Review of Maritime Transport 2019, U.N. Doc. UNCTAD/RMT/2019/Corr.1, at 1-10 (Jan. 31, 2020); 


\section{The Legal Framework}

Since the start of modern history, pirates have been "the enemy of mankind," a title arising from the ancient legal phrase "hostis humani generis [that means] a pirate is not included in the list of lawful enemies but is the common enemy of all. ${ }^{\prime \prime 4}$ The substance of that phrase is reproduced in the laws of most nations and conveys universal jurisdiction over all acts of piracy. ${ }^{85}$

International law governs conduct on international waters - the high seas - and is derived from treaties, normative state conduct, credible commentary, and resolutions of international bodies such as the UN. ${ }^{86}$

Within authoritative international law - both treaty and custom - is the firm principle of states' freedom to navigate the high seas. Navigation, defined as steering or directing a ship, is thus protected by a common understanding, under international law, that "all states normally have a duty not to interfere with foreign ships outside [that state's] territorial waters." ${ }^{87}$ Put differently, "[i]n places where no local authority exists, where the subjects of all States meet upon a footing of entire equality and

see also Int'1 Chamber of Commerce, Int'1 Mar. Bureau, 2019 Annual Rep. on Piracy and Armed Robbery Against Ships, at 5-7 (Jan. 2020) (illustrating that from 2015 to 2019, occurrences of piracy decreased each year except for 2018, which saw 201 incidents compared to 180 in 2017); see also Gregory Clough \& Morgan D. Bazilian, New Coalition in Gulf May Not Fare as Well as Old, YALEGLOBAL ONLINE (Nov. 21, 2019), https:/ /yaleglobal.yale.edu/content/new-coalition-gulf-maynot-fare-well-old (explaining that premiums imposed on insured vessels' transit of the Strait of Hormuz increased from \$30,000 to over \$300,000 during spring 2019); see also Income up 15\% at fixed premium insurer DGS Marine, SEATRADE MAR. NEWS (Mar. 16, 2015), https://www.seatrade-maritime.com/europe/income15-fixed-premium-insurer-dgs-marine; see also

Kidnap and Ransom Insurance: At an Inflection Point, COGNIZANT 5 (Oct. 2015), https://www.cognizant.com/whitepapers/Kidnapand-Ransom-Insurance-At-an-Inflection-Point-codex1575.pdf (explaining that the $K \& R$ market grew at a rate of $12.25 \%$ from 2010 to 2015 , after increasing by $30 \%$ from 2008 to 2010, according to publicly available data reported by Hiscox, which yielded a market estimated in value in 2015 to be $\$ 4.37$ billion); see also Top names in marine insurance sector call for regional alliance, HELLENIC SHIPPING NEWS WORLDWIDE (Nov. 25, 2018), https:/ / www.hellenicshippingnews.com/top-names-in-marineinsurance-sector-call-for-regional-alliance/.

${ }^{84}$ See, e.g., Thomas J.R. Stadnik, Esq., Pirates: Common Enemies of All, the Enemies of the Human Race, the Law of War, and the Rule of Law, LeXisNeXis Legal News RoOM (May 5, 2009), (citing Marcus Tullius Cicero, DE OfFICIIS Book III, Ch. XXiX, 107), https://www.lexisnexis.com/legalnewsroom/internationallaw/b/international-law-blog/posts/pirates-_2d00_-thecommon-enemies-of-all_2c00_-the-enemies-of-the-humanrace_2c00_-the-law-of-war-and-the-rule-of-law (cited by President Obama in his inaugural address).

${ }^{85}$ See id. ("[u]niversal jurisdiction over piracy is based on the fact that piracy is abhorrent to all nations where the rule of law prevails - that is clear even from Cicero's day - and should be independence, no one State, or any of its subjects, has a right to assume or exercise authority over the subjects of another". ${ }^{88}$

The United Nations Convention on the Law of the Sea (UNCLOS) defines piracy as any violent or depredate act that is "committed for private ends ${ }^{89}$ by the crew [of a private ship] against another [ship, or its passengers or property, that occurs in waters] outside the jurisdiction of any State [such as the high seas]". ${ }^{90}$ The UNCLOS definition is the most common codification of piracy. ${ }^{91} \mathrm{In}$ short, UNCLOS gives states equal, limitless, and discretionary jurisdiction over acts of piracy.

Another law, also established under UNCLOS, decides whether pirates are treated under international, or state, law. The rule of flag state sovereignty permits a vessel owner to register ("flag") her vessel in any sovereign state ("flag state") whose laws have full jurisdiction over the vessel and its operation. ${ }^{92}$

Piracy occurs mostly in coastal waters under jurisdiction of the coastal ("littoral") state that is primarily responsible to

punished wherever and by who[m]ever is in the position to [do so].").

${ }^{86}$ See GlenN H. ReynOldS \& ROBERT P. MERGES, OUter SPACE: Problems OF LAW \& POlicy 8, 25 Westview Press (2d ed. 1997) (treaties are formal agreements between sovereign nations that, though "seem[ingly legalistic", are no less formative to international law than is custom, defined as "general principles of international law not embodied in any treaty but observed, and considered binding by civilized nations").

${ }^{87} \mathrm{Id}$. at 31 .

${ }^{88} \mathrm{Id}$. at 32 (citing a British judge in the famous admiralty case, Le Louis, 2 Dod. 243).

${ }^{89}$ Chris Dent, Nordenfelt $v$ Maxim-Nordenfelt: An Expanded Reading, 36 ADELAIDEL. REV. 329 (2015). See 18 U.S.C. § 1651 (1958); see, e.g., United States v. Shi, 525 F.3d 709 (9th Cir. 2008) (finding homicidal mutineer-cook a pirate); see also United Nations Convention on the High Seas, Apr. 29, 1958, 450 U.N.T.S. 11(illustrating further codification of the crime of piracy, particularly that UNCLOS delineates private and public as whether the actor has any state affiliation).

${ }^{90}$ United Nations Convention on the Law of the Sea, art. 101(a), Dec. 10, 1982, 1833 U.N.T.S. 397.

${ }^{91} I d$. See Int'l Mar. Org. [IMO], Assembly Res. A.1025(26), Code of Practice for the Investigation of Crimes of Piracy and Armed Robbery Against Ships, A 26/Res.1025(Dec. 2, 2009); see also Int'l Mar. Org. [IMO], Piracy: elements of national legislation pursuant to the United Nations Convention on the Law of the Sea, 1982, III10-17, LEG 98/8/1(Feb. 18, 2011).

${ }^{92}$ United Nations Convention on the Law of the Sea, arts. 94, 24(1)(b), 217, 227 Dec. 10, 1982, 1833 U.N.T.S. 397. See infra note 154 and accompanying citations; see also Piracy on the High Seas: Protecting Our Ships, Crews, and Passengers Hearing Before the S. Subcomm. on Surface Transp. E Merch. Marine Infrastructure, Safety, $\mathcal{E}$ Sec. of the S. Comm. on Commerce, Science, E Transp., 111th Cong. (2009). 
prevent piracy in those waters. ${ }^{93}$ However, forceful responses to prevent most acts of piracy where they occur are often implausible due to deficient state infrastructure and, more importantly, the use of the high seas international territory where pirates can prepare to act and flee after acting. Thus, acts of piracy are, in some ways, impossible to fully prevent. Yet, international law provides the legal standard for the framework that this Article proposes.

A global treaty (like all regulations imposing universal limitations on international territories) must first comply with international law - after all, compliance with a treaty by states that ratify it will eventually create customary international law from that treaty itself. ${ }^{94}$ Numerous conventions are ripe for ratification, and the proposed regulation could be incorporated into a revised or treaty or even a revised ratification. ${ }^{95}$ Thus, the analysis of a regulation that ensures compliance with a speed limit must be based on existing state rules and normative state practices.

However, lest we forget, pirates are enemies of mankind. To effectively mitigate the criminal acts of pirates, piracy must be insured. Secrets are a reality of the market. The international approach toward forceful defense are, at present, not feasible. Each year prevention methods are

${ }^{93}$ Munich Re Group, Piracy-Threat at sea, MÜNCHENER RÜCK, Sept. 2006, at 20, http://www.fortunes-demer.com/mer/images/documents\%20pdf/documents_piracy/ MunichRe_Piracy_at_Sea_A_Risk_analysis_2006.pdf (explaining that around $80 \%$ of piracy acts occur in coastal waters -in general, those waters lying within 12 nautical miles of littoral states with linear coastlines -and the other $20 \%$ occurs in non-coastal waters). See United States Counter Piracy and Maritime Security Action Plan, HOMELAND SECURITY DIGITAL LIBR., June 2014, at 4, https:/ / www.hsdl.org/?view\&did=755125 (explaining that the absence of sufficient governance and "adequate maritime security measures" are "primary factor[s]"that allow "piracy and related maritime crime to flourish"). Freedom C. Onuoha, Piracy and Maritime Security in the Gulf of New Guinea: Trends, Concerns, and Propositions, 4 J. Middle East \& Afr. 267 (2013). See Int'l Mar. Lecturers Ass'n, Modern Challenges in Maritime Education and Training, at 441-42 (Sept. 23-25, 2019) (explaining that the International Maritime Bureau (IMB) Piracy Reporting Centre observes that "attacks intensify in the territorial waters of less developed countries where security gaps are high"). Andrew Chamberlain \& Rebecca Warder, THE SHIPPING L. REV. 73 (George Eddings, Andrew Chamberlain, \& Holly Colac,oeds., 6th ed. 2019) (" $\mathrm{t}]$ he territorial waters of the littoral states extend to 12 nautical miles from their respective base lines and their exclusive economic zones [likewise] to 200 nautical miles.").

${ }^{94}$ See Mar. Env't Prot. Comm., Int'1 Mar. Org. [IMO], Prevention of Air Pollution from Ships, MEPC 53/4/4, at 2 (Apr. 15,2005) (illustrating how the IMO's navigation committee approved a slow steaming mandate); see also Int'l Mar. Org. [IMO], Res. MEPC.176(58), MEPC 58/23/Add.1, at 19 (Oct. 10, 2008) (setting forth sulfur standards and the NOx Technical Code).

${ }^{95}$ See, e.g., Mar. Env't Prot. Comm., Int'1 Mar. Org. [IMO], Report of the Marine Environment Protection Committee on Its Seventy-Fourth Session, MEPC 74/18, annex 11 (June 9, 2019). See generally Piracy enhanced, new mechanisms are created, and the standards covering piracy risk are reviewed for improvement. But still, there remains the problem of excessive costs. The following section proposes a solution in the form of a new regulatory system.

\section{The Regulatory Framework}

This regulatory framework advocates faster transit of HRAs by merchant vessels to lower the costs preventing piracy. To date, more than one half of all vessels travelling through HRAs travel at or above a speed of 18 knots. ${ }^{96}$ Data from the United States shows that the "ships most vulnerable to attack are those with low top speeds, both [those vessels that are] proceeding slowly through the [HRAs] and [those that are] unable to accelerate to a high rate of speed". ${ }^{97}$

In a letter to U.S. President Barack H. Obama dated April 24, 2009, the American Maritime Officers stated that "[s]peed is the most important factor to avoid and prevent pirate boarding. There are very few U.S.-flagged vessels which operate near the HRA that have a top speed of less than 20 knots." ${ }^{\prime 98}$ If the ship is travelling at or faster than 18 knots $(33 \mathrm{~km} / \mathrm{h})$, it stays unassailable by pirates. ${ }^{99}$

on the High Seas: Protecting Our Ships, Crews, and Passengers Hearing Before the S. Subcomm. on Surface Transp. \& Merch. Marine Infrastructure, Safety, ES Sec. of the S. Comm. on Commerce, Science, E Transp., 111th Cong. (2009) (explaining international law).

96 Rahie M. Bali, Piracy Risk and Mitigation Framework (2012/2013) (unpublished M.Sc. thesis, Erasmus University Rotterdam), https://thesis.eur.nl/pub/33040/Bali-R.-PiracyRisk-and-Mitigation-Framework.pdf (vessels travelling east-west are more fully laden and thus prone to piracy risk; oil tankers have lower freeboard than bulk carriers due to onboarding pump equipment; freeboard information from International Load Line Convention; speed was highest scoring of all key security factors in the study, beating access, reporting, geography, freeboard, conditions, lookout, anti-piracy equipment).

${ }^{97}$ Hearings, supra note 103.

${ }^{98}$ See Piracy on the High Seas: Protecting out Ships, Crews \& Passengers Before the Subcommittee on Surface Transportation \& Merchant Marine Infrastructure, Safety and Security of the Committee on Commerce, Science \& Transportation, U.S. Senate, 111th Congress 1st Session (2009) (it is for this reason that cruise ships are not at high risk of piracy - high speeds, high freeboards - not to mention they more often carry security on board than merchant vessels do).

${ }^{99}$ E.g., A study of the impact of weather conditions on piracy off the Horn of Africa in 2011 (Cook, Garrett, Rutherford (2011). See Sam Bateman, Confronting Maritime Crime in Southeast Asian Waters: Reexamining "Piracy" in the Twenty-First Century, in 35 NAVAL WAR COLLEGE NEWPORT PAPERS at 144 (2010). But see BIMCO, War Risk Clause for Time Charters 2004 (CONWARTIME 2004), https://www.bimco.org/contracts-and-clauses/bimco-

clauses/earlier/war_risk_clause_for_time_charters_2004 (last visited Mar. 9, 2021) (BIMCO allowed owners to refuse to proceed where, in the reasonable judgement of the master, the vessel or 
Interestingly, vessels must maintain speeds of at least 18 knots in the Somalian HRA. ${ }^{100}$ Studies utilizing real-time vessel tracking have confirmed that lower speeds equal higher piracy risk and, further, that seasons of relatively low piracy risk are distinguished by shipping practices that shift to lower speeds and shorter routes. ${ }^{101}$

The primary cost of enacting the regulation proposed in this Article is attributable to greater fuel consumption. Correspondingly, in light of regulating high speeds for HRA-transit vessels, the most direct savings are the time and risk saved from those extra-optimal speeds. Accordingly, the main costs are the consumption of fuel over and above that which would have been consumed but for the extra-optimal speeds.

Theoretically, then, reductions in premium surcharges on the policies covering the risk thereby reduced by vessels transiting an HRA at (regulation-compliant) extra-optimal speeds would break even in a vessel-specific, cost-benefit analysis. Unfortunately, that assumes no transaction costs and accessible, reliable information-sharing among insurers, regulators, and shippers. ${ }^{102}$

crew or cargo or any others on board the vessel would be exposed to war risks. Or, if they did proceed, they would be indemnified for extra costs).

${ }^{100}$ Tillmann Kratz, Expert on Facultative Risks and Corporate Underwriting (2019). The height of the freeboard is a relative protection, as a vessel with more than 8 meters of freeboard has a better chance to escape. See Wouter Klijnsoon, A Situational Analysis of Opportunity-Reducing Prevention Measures Against Contemporary Somali Maritime Piracy on Ships in the High Risk Area: Technoprevention or Armed Guardianship? (Dec. 16, 2015) (unpublished M.Sc. thesis, Vrije Universiteit Amsterdam), https://www.academia.edu/20170382/A_Situational_Analysis_ of_Opportunity_Reducing_Prevention_Measures_Against_Cont emporary_Somali_Maritime_Piracy_on_Ships_in_the_High_Ris k_Area_Technoprevention_or_Armed_Guardianship

[hereinafter Situational Analysis] (evaluating physical security mechanisms and their deterrence effect on piracy by consulting academic literature, public reporting; and fourteen interviews). There is no known case of a successful attack on a vessel travelling at or above 18 knots. Id.

${ }^{101}$ E.g., Michele Vespe et al., The Declining Impact of Piracy on Maritime Transport in the Indian Ocean: Statistical Analysis of 5-Year Vessel Tracking Data, 59 MARITIME POLICY at 9-15 (2015), http://dx.doi.org/10.1016/j.marpol.2015.04.018. See also Int'1 Mar. Org., Rep. on Acts of Piracy and Armed Robbery Against Ships, MSC.4/Circ.264 (Apr. 27, 2020) ("About 70\% of incidents reported in 2019 were targeting a steaming ship. This is a significant percentage compared to the global average of about $34 \%$.").

102 U.N. CONF. ON TRAdE \& DEV., REVIEW OF MARITIME TRANSPORT 2019, at 40, UNCTAD/RMT/2019/Corr.1, U.N. Sales No. E.19.II.D.20 (2020) ("[a]ny discussion on fuel economics is also linked to the debate on carbon emission control. One such approach being considered at IMO," as a decarbonization measure against slow steaming, "relates to the setting of mandatory speed restrictions on ships." The approach was rejected by container shipowners who thought "that imposing
In the first instance, the "navigational" speed of vessels is an environmental concern. A framework imposing navigational directives affecting speed may implicate pollution, marine life, or crew safety. Further, altering the speed at which vessels navigate would result in fuel consumption at either extra-optimal or suboptimal levels of emission volumes. ${ }^{103}$

Conveniently, UNCLOS alone prescribes navigation on the high seas. ${ }^{104}$ The extension of the coastal States' rights under UNCLOS is balanced by a liberal regime for navigation. This consists of an express right granted to States for freedom of navigation in all non-private waters as well as the right of innocent passage through territorial seas excluding straits and archipelagic lanes. ${ }^{105}$

However, UNCLOS does not provide for the rights and obligations of private parties. ${ }^{106}$ Thus, the legality under international law of a framework controlling vessel speeds within pirate waters (waters deemed to present heightened risks of piracy) relies upon whether the freedom of navigation permits such control. ${ }^{107}$

mandatory speed limits would undermine technological advances necessary for decarbonizing shipping and could jeopardize the broader objective of climate change mitigation").

${ }^{103}$ Shipowners may seem to operate their vessels in ways that are not the most fuel-efficient. To the extent that emissions exceed the perfect ideal, other costs are saved; while those costs are not donated to the environment, per se, the control of emissions is the most efficiently monitored and incentivized interest within the context of competing environmental and shipping interests (compared to, for instance, the current methods of handling whale strikes, where chances of vessel-whale collision can be mitigated by vessel operation - slowing transit speed or avoiding potential breeding grounds. This is, however, difficult to monitor and, therefore, difficult to control.

${ }^{104}$ See United Nations Convention on the Law of the Sea, Dec. 10, 1982, 1833 U.N.T.S. 397 [hereinafter UNCLOS] (outlining the rights and obligations of States in relation to their jurisdictional zones with respect to marine environmental protection).

${ }^{105}$ Id. Art. 58.

${ }^{106}$ See generally id. A right of navigation in the high seas is granted to all States under Article 90; freedom of navigation is part of freedom of the high seas granted to all States by Article 87. Id. at Art. $87 \& 90$. However, the exercise of the freedom of navigation in the EEZ is subject to rules and regulations imposed by the littoral State in accordance with UNCLOS as well as other standards of international law that are not incompatible with UNCLOS.

${ }^{107}$ Similarly, a littoral State could singularly, or in cooperation with other littoral States, attempt to effectuate the same international law by unilaterally imposing the same regulation to prevent the costs and threats of piracy. Freedom of navigation is a broad concept whether "navigation" pertains to free vessel movement between two points or, rather, under full control of its master. Yet, freedom of navigation could be reconciled with speed restrictions either way - for example, by mandating two points instead of mandating speed, thus enabling directives of routes by the flag state. 
If normative practice, rather than the rule of flag state control, was the basis for an agreement between states, the port states could exercise control of ships flying other states' flags upon entrance to their ports (as is permitted by port state control). ${ }^{108}$ Compliance could be achieved onboard the vessel if a vessel's flag state prefers to insist upon restricting inspection as far as the flag state rule permits. ${ }^{109}$ Also, the regulatory framework could provide, or permit the regulating body permission to so provide, exemptions for certain circumstances where compliance makes less sense - for example, exemptions for timesensitive cargo or for certain categories of emergencies. ${ }^{110}$

Under this authority then, an agency such as the IMO could enact this regulation through a treaty or, better still and more timely, a treaty revision. Regional speeds for different ships are ideal, as verifying speed is possible with the technology of Exact Earth and AiS, which enable realtime vessel tracking. ${ }^{111}$ Penalties could be vested, theoretically, in the private insurance contracts themselves, whose terms could provide for surcharges for substandard speeds and non-compliant navigation.

${ }^{108}$ International Convention for the Prevention of Pollution from Ships, Nov. 2, 1973, 1340 U.N.T.S. 184, as amended by Protocol of 1978, Feb. 17, 1978, 1340 U.N.T.S. 62 [hereinafter MARPOL] (imposing on contracting states the requirements of the Convention as may be necessary to prevent disparate treatment of vessels. Thus, contracting States to MARPOL use their prescriptive and enforcement power to require compliance with MARPOL as conditions for entry to their ports, regardless of whether they are party to the agreement).

${ }^{109}$ Regulations imposed by flag states must be followed and are only subject to other restrictions or regulations that are imposed by a State when the vessel is in her territorial or internal waters. Intersessional Working Group on Reduction of Greenhouse Gas Emissions, Report, MEPC 71/WP, (September 18, 2020), 5. See UNCLOS, supra note 112, at Art. 25(2) (ships in transit passage have to proceed without delay and the transit must be 'continuous and expeditious' but, at the same time cannot be obstructed.

${ }^{110}$ MARPOL, supra note 116, at Annex VI (assuming the littoral states are a party to MARPOL). Regulation of territorial waters, in case of a global agreement, would be the sole obligation of the littoral states, regardless of whether such waters fell within HRA (or other) boundaries denoting some heightened risk. Id. (slow steaming would likely except its mandate from applying to piracy, after all).

${ }^{111}$ Regional speed controls are less certain since they create variant regulations across a region and could distort market competition. In the context of ocean commerce, the distortion would be large since the regional regulation itself would only apply to vessels by virtue of which State flag the vessel flies. Thus, vessels could avoid the regulation not only by avoiding the port but also by changing flags. Different speeds similarly impose market distortions in the short term. Shipowners hire and build vessels for operation based on industry conditions. Imposing anything but a customized speed restriction would be to change metrics upon which shipowners make business decisions - it would be unfair and inefficient. Most shippers categorically reject a one-speed-fits-all solution. See Int'l Chamber of Shipping (ICS),

\section{Some Considerations in Light of Slow STEAMING}

Since January 2020, an IMO-enacted statute ("IMO 2020") is enforceable against merchant vessels worldwide and gives shipowners three options - each more expensive and, importantly, more protective of the environment than the preceding regulatory standards, that are: (1) switch to lower sulphur fuel oil, (2) use traditional fuel as before 2020 but also install exhaust cleaning systems ("scrubbers"), or (3) use alternative fuel such as methanol or natural gas ("LNG"). ${ }^{112}$

The goal of implementing IMO 2020 was to achieve a 50\% reduction in the global emission of greenhouse gas by 2050, which requires reducing the Sulphur cap for fuel oil from $3.5 \%$ to $0.5 \%$. Most vessels switched to compliant fuel, although the minority that elected the steep expense of installing scrubbers were commonly among the largest vessel classes - the industry's most fuel-guzzling ships had the larger incentive to avoid higher fuel prices. ${ }^{113}$

Specifically, slow steaming involves adapting engines designed for a specific speed of 22-25 knots, implying that

Annual Review, at 34 (2018), https:/ / maritimecyprus.files.wordpress.com/2018/05/icsannual-review-2018.pdf ("ICS remains strongly opposed to the concept of IMO establishing a mandatory system of operational efficiency indexing for application to individual ships. This is because the potential inaccuracies of such a metric and the significant danger of market distortion"). IMO regulations require that the AIS systems on SOLAS vessels provide information automatically to appropriately equipped shore stations. IMO has the power to impose frameworks even on insurance coverage of vessels within certain zones according to certain speed.

112 Int'l Mar. Org., IMO 2020: Taking Bold Action to Clean Up Shipping Emissions by Reducing the Sulphur Content in Ships' Fuel Oil,

https://wwwcdn.imo.org/localresources/en/MediaCentre/Ho tTopics/Documents/Sulphur\%202020\%20infographic\%202\%20p age.pdf (last visited Mar. 9, 2021); Garuav Sharma, Exxon Mobil Eyes Marine Fuels Business Expansion as IMO 2020 Deadline Looms, FORBES (Mar. 13, 2019, 1:19 PM), https://www.forbes.com/sites/gauravsharma/2019/03/13/ex xonmobil-eyes-marine-fuel-business-expansion-as-imo-2020deadline-looms/\#6f99ae397a6e.

113 See, e.g., MARITIME EXECUTIVE, Scrubber Installations Continue With Containerships Leading the Way (Aug. 14, 2020), at https://www.maritime-executive.com/article/scrubber-installationscontinue-with-containerships-leading-the-way (noting that about "13 percent of the main cargo carrying ship types, approximately 2,600 of the roughly 20,000 commercial cargo-carrying ships, [were] fitted with scrubbers [while larger vessels,] which by nature consume(sp) more fuel, according to BIMCO have been the ones to adopt scrubber technology versus the smaller [types or] classes of commercial cargo ships"); and The Scrubber Option Versus the LNG Option, TANKER OPERATOR, at 26-27 (Apr. 2019), http:/ / ea45bb970b5c70169c61-

0cd083ee92972834b7bec0d968bf8995.r81.cf1.rackcdn.com/TOAp r19.pdf. 
for that speed they run approximately at $80 \%$ of full power capacity. However, this process requires "derating" the main engine to reduce its power level to $70 \%$ through changing the timing of the fuel injection and adjusting exhaust valves. Continual slow steaming is simply not ideal. At "slow-steaming" speed, vessels operate their engines below their ideal capacity to save fuel consumption at the expense additional travel time, particularly over long distances. ${ }^{114}$

Slow steaming is likely to soon become the dominant operational speed, as more than $50 \%$ of the global container shipping capacity operate under such capacity. ${ }^{115}$ Slow steaming is an expected result of implementing IMO 2020, which will include increased transit times, decreased vessel supply, and decreased fuel prices. ${ }^{116}$ According to the ICC, more than half of pirate attacks occurred on slowsteaming vessels in 2019, even though slow steaming is not likely as common as that same figure. ${ }^{117}$

To fortify the framework presented by this Article, consider a ship-by-ship study analyzing the costs and benefits of fuel consumption - by price of fuel (which changes daily) for each type of vessel (tanker, bulker, and container, so on) - versus reduced insurance premiums. I do not suspect the numbers are close - here, there is much to be saved and, importantly, more to be saved than spent.

${ }^{114}$ Bunker fuel comprises at least half of shipping's operating
expenditures, and the most fuel-efficient (cost-efficient) operation
of any vessel is to maintain (as close to) a constant speed during
the entirety of its transit. A. Graf von Westarp, A New Model for the
Calculation of the Bunker Fuel Speed-Consumption Relation, OCEAN
ENG'G, Vol. 204, No. 107262, Mar. 27, 2020, at 1 \& 3,
https://doi.org/10.1016/j.oceaneng.2020.107262.
${ }_{115}$ See Fuel Consumption by Container Ship Speed and Size, THE
GEOGRAPHY OF TRANSPORT SYSTEMS (adapted from Nottenboom, T.
and P. Carriou (2009) "Fuel surcharge practices of container
shipping lines: Is it about cost recovery or revenue making?".
Proceedings of the 2009 International Association of Maritime
Economists (IAME) Conference, June, Copenhagen, Denmark), at
https://transportgeography.org/contents/chapter4/transportat ion-and-energy/fuel-consumption-containerships / ("[e]xtra slow steaming (15-18 knots; 27.8 - $33.3 \mathrm{~km} / \mathrm{hr}$ ) [involves a] substantial decline in speed to achieve a minimal fuel consumption level while still maintaining a short commercial service [and] can be applied to specific short-distance routes").

${ }^{116}$ Flexport Contributor, IMO 2020: What Shippers Need to Know Now, FORBES (Apr. 8, 2019, 2:09 PM), https: / www.forbes.com/sites/flexport/2019/04/08/imo-2020what-shippers-need-to-know-now /?sh=59d6ea64812d.

${ }^{117}$ Menghie Jin \& Wenming Shi, et al., Marine Piracy Prediction and Prevention: Policy Implications, MARINE POLICY, Vol. 108, No. 103528 (May 30, 2019), https://doi.org/10.1016/j.marpol.2019.103528 (small vessels or open registry vessels more likely targets); Marie-Claire Robitaille, Maritime Piracy and International Trade, 31 Defence and Peace Economics 957, 958 (2020) (suggesting using maritime, rather than great-circle, distance as the primary metric to access a voyage's likelihood of piracy incidence). See Maritime Piracy,
Simply put, the shipping industry controls the most important variables that make a vessel at risk of piracy, at all. Shipowners often respond to increased fuel prices by implementing chronic slow steaming; and they do so to cut operation costs, rather than to benefit the environmental or global-economic agenda. ${ }^{118}$ Faster speeds means fewer pirates. ${ }^{119}$ The authority for mandating slow steaming, and the agency by which enforcing such mandate is possible, are identical to the authority and agency that are ideal to enact and enforce the proposed regulation to "speed up" ships in pirate waters.

\section{CONCLUSION}

Today, piracy is fundamentally different than it used to be. Pirates no longer roam the sea reaping grotesque rewards. Rather, pirates thrive in localized waters confined to boundaries that are bilaterally established by sovereign states as lawful limits to their freedom. These limits enable piracy to thrive where, as always, it can prey on the unprotected.

Modern piracy is not fully eradicated; but it is quickly losing the fight. Just as normative laws among nations mandate the use of force on the high seas, cooperative information, research, and innovation can achieve a regulation as is envisioned here. Indeed, such global

\section{MARITIME SECURITY REVIEW (2010),}

http:/ /www.marsecreview.com/wp-

content/uploads/2010/10/Piracy-Report-v6.pdf

(Hiscox announced $50 \%$ premium reduction for ships with armed protection).

${ }^{118}$ An interesting study conducted by scholars Theo Notteboom and Pierre Carriou found that faster vessels will often elect a less indirect shipping lane when sailing routes that pass through HRA waters while slower ships more often opt to re-route. Fuel Surcharge Practices of Container Shipping Lines: Is It About Cost Recovery or Revenue Making?, INT'L ASS'N OF MAR. ECONOMISTS CONF. (June 24-26, 2019). while slower ships more often reroute". However, even if the economic consequences of extra fuel use exceed the corresponding benefits, the issue is primarily one of incentives.

119 Above-eighteen-knot speed renders vessels essentially unassailable. Sailing at higher speeds, especially at or above 18 knots, reduces the likelihood of being boarded by pirates. See generally, Vespe, supra note 109, at 12. See also TOWERGATE INSURANCE, 2018. Troubled Waters: The Global Price of Piracy, at https://www.towergateinsurance.co.uk/boat-insurance/globalprice-of-piracy ("[n]o pirates have ever boarded a ship pushing 18 knots, or nearly 21 miles per hour"); OCEANS BEYOND PIRACY. 2012. The Economic Cost of Somali Piracy (2013), 22, at https://oceansbeyondpiracy.org/sites/default/files/ecop2012fi nal_2.pdf ("no ship making over 18 knots has ever been captured by pirates", citing to Tristan McConnell, Pirates: The Economic Costs of Maritime Crime, THE WORLD GLOBAL POST (March 16, 2012), at https:/ /www.pri.org/stories/2012-03-16/pirates-economiccosts-maritime-crime (no ship traveling at 21 miles per hour, or 18 knots, has been hijacked by pirates). 
cooperation continues to prove increasingly effective at achieving the goal of this paper - to deter piracy.

Insurance is an excellent vehicle to induce private incentives. However, like the law that governs it, piracy insurance is dynamic. Insurance is most beneficial when its policies most effectively spread cost and mitigate risk. But, as costs and risks change, so must insurance. To succeed now, in the period of piracy's decline, there must be a renewed recognition of the recent change in piracy risk.

This does not amount to any windfall to shippers, nor to the economy. Short-term profit is not a near-certainty of this regulation. What is certain, at this point, is that there is no need to end coverage against the risks of piracy. In fact, there may never be. After all, piracy began when seafaring began and it may remain that way. Today, piracy should be insured, but with a realistic perception of the impossibility of calculating its risks and payoffs - its cost, its price.

In the meantime, the same framework which safeguards the high seas in keeping its waters free of weapons under color of law can - by the same authority, with the same body, in the same process - make headway toward eliminating the threat of modern piracy.

As this Article has outlined, the IMO has both the capacity and the authority to implement a regulatory system that enables its body to enforce imposition of speed minimums as limitations within the HRAs as defined by the JWC without violating the freedom of navigation. Penalties for violating the regulation are easily envisioned within the terms of the private insurance contracts which, themselves, envision the speed limits mandated by the IMO.

The limitations are mechanically and economically feasible, especially in light of impending slow steaming guidelines or mandates. The regulation is enforceable under international law as it can be monitored with current, recent vessel-tracking technology. The limitations imposed by the regulatory framework are fully permissible under, and can apply concurrently with, the powers of port state control and flag state sovereignty.

In short, this Article advocates a treaty revision allowing the IMO to mandate the speeds of vessels navigating the pirate-prone waters within the currently defined HRAs. If done correctly, and promptly, this regulation will induce self-interested shipwoners to run the gauntlet. Thereby, a rational shipowner will save more dollars from reduced premiums than it spends on extra fuel consumption. Thus, in running (sailing) the gauntlet, the world economy is one large step closer to removing the need to pay the pirate.

$--0--$

\section{Acknowledgement}

The author has a J.D. ('21) from the University of Tennessee College of Law and is grateful to Tennessee Law Review's Kaleb Byars (Editor-in-Chief) and Bailey Barnes (Managing Editor) for insightful edits of this Article. 